\section{O editor e o livro: marcas mediadas e afetivas}

DOI: 10.1590/1809-58442016213

\section{Libny Freire}

(Universidade Estadual do Rio de Janeiro, Faculdade de Comunicação Social, Programa de Pós-Graduação em Comunicação Social. Rio de Janeiro - RJ. Brasil)
Helton Rubiano

Ensaios de editor

RUBIANO, Helton. Ensaios de um editor: pensando livros, projetos e práticas. Natal, EDUFRN, 2015. 116p.

O livro Ensaios de um editor: pensando livros, projetos e práticas é um relato saído de dentro das quatro paredes de uma editora universitária e se divide em 12 capítulos que abrangem os diversos setores. Pautado nas experiências do autor Helton Rubiano como editor da editora universitária da Universidade Federal do Rio Grande do Norte (Edufrn), tem a proposta de iniciar reflexões acerca da edição de publicações.

Em seu primeiro capítulo, O que é o livro, há um breve histórico sobre o nascimento do livro a partir das materialidades, como as inscrições em pedras e folhas até chegarmos a Gutenberg. É apresentada a discussão relativa aos novos formatos de leitura e em como esses novos dispositivos fazem surgir novas definições para o que seja "livro". Pensando-o como um objeto que representa - e registra - o conhecimento, podemos compreendê-lo como um promotor do conhecimento e da produção intelectual e cultural, ambos interligados em uma sociedade.

Ao entendermos essa característica principal do livro, intrinsecamente ligada à promoção do conhecimento, ainda mais quando falamos em editoras universitárias, temos a figura do editor apresentada no capítulo Quem é o editor, a quem é atribuída a intervenção nos textos, que vão desde a seleção do material até o seu lançamento. O editor está ligado aos demais profissionais da produção editorial, como o revisor, diagramador, capista e, claro, o autor. É uma árdua tarefa pensar e designar porque tal livro é relevante em detrimento de 
outro, mas ao editor, cabe selecionar uma comissão/conselho editorial para que o auxiliem nessas decisões.

Em várias mãos sobre o mesmo livro, temos o caminho percorrido do texto submetido até tornar-se um livro, pois é importante ater-se ao fato de que há um texto inicial do autor e um texto final após o processo editorial. Essas transformações irão depender da qualidade do texto entregue pelo autor e da qualidade exigida pela editora, ou seja, a editora irá dar a “sua cara” ao texto para que se torne um livro no padrão de qualidade da instituição.

O processo de produção editorial é longo, nem todos compreendem que é preciso tempo, aliado a muita atenção e olhadelas no orçamento do livro para que este aconteça. Do livro proposto, avaliação do conselho editorial, revisão de originais, revisão de provas, capista e conversas com autor e editor lá se vão bons meses. Isto é bem colocado na obra, a partir da enumeração e explicação de cada um dos processos. Em Por que revisão? fica bem claro o papel do revisor de texto, que além de tudo, é um crítico do texto - e veja bem, não crítico do autor - com a finalidade de levar ao público uma leitura clara, sem brechas de interpretação, ou seja, bons textos. Para falar da apresentação do livro, Design de livros: o prazer pelos sentidos enumera a importância da materialidade, mesmo que o suporte seja o papel ou um dispositivo de leitura. Para uma boa capa e miolo são necessárias técnica e sensibilidade, que obviamente, estão pautadas no orçamento que se tem para produzir determinada obra. Livro bonito é o objetivo, desde que esteja dentro do orçamento. Ao discutir os processos - e limitações - para a construção do livro, é importante levarmos em consideração As emoções do autor, nas quais é preciso cautela do editor e toda produção editorial para que haja um relacionamento harmonioso e, acima de tudo, de negociação. Rubiano, corretamente, frisa que o autor não é um profissional de editoração e, por isso, é preciso que haja limites nesse relacionamento.

Quando todos podem ser autores promove uma rápida discussão sobre a tendência das auto publicações - selfpublishing - que é o autor se publicando, mostrando seu trabalho, sem a presença de um editor ou conselho editorial, que de certa forma, dão legitimidade à obra publicada. Entre papéis e bytes retoma a fala inicial do Rubiano em relação ao livro de papel e o livro digital (e-book). É interessante o questionamento proposto: o e-book não é um livro. Nesse caso, o livro seria a invenção perfeita, como por exemplo, a roda, e o que viria após isso seriam melhoramentos, nesse caso, relacionados à materialidade. A importância do livro digital é observada a partir da democratização do acesso, ou seja, ao conhecimento. $\mathrm{O}$ autor entende que papel e dispositivo digital são experiências diferentes, para necessidades diferentes. A palavra chave deste capítulo é coexistência.

Nos últimos capítulos, o autor adentra em temas mais técnicos como os tipos de acabamento de papel e impressão (Sobre papéis: possibilidades materiais); sobre a distribuição do material e seu êxito em chegar ao leitor (Asas aos livros: distribuição); 
fornece também um guia para publicar em editoras universitárias, tendo como referência a Edufrn - o roteiro é muito útil para aspirantes a autores, tanto pela linguagem quanto pela estrutura (Os livros e as ciências: publicações acadêmico-científicas). Em Editoras universitárias: o que e para quem publicar? há uma discussão sobre o papel das editoras universitárias, a partir da universidade enquanto instituição do saber, responsável pela difusão do conhecimento promovido pelas suas diversas áreas.

Ensaios de um editor: pensando livros, projetos e práticas se propõe a analisar os diversos setores que atuam dentro de uma editora universitária e faz isso muito bem. A intimidade do autor com as situações corriqueiras do processo editorial aproximam o leitor desse universo. A discussão sobre a relevância de livro digital e livro de papel é pertinente, principalmente quando falamos em consciência ambiental, pois não se concebe a ideia de escrever um livro impresso de 300 páginas contrário ao desmatamento. O livro é pertinente para a área de editoração, para levantarmos questionamentos sobre o papel das editoras universitárias - com ênfase na sociedade em geral - sem restrição ao público acadêmico. Para os interessados em saber como funciona o processo editorial e também para os que desejam publicar suas produções acadêmicas, trata-se de leitura recomendada e necessária. A obra nos mostra caminhos possíveis e com uma linguagem na qual é perceptível o afeto do autor. E como editor, deixou marcas e devo dizer, boas.

Libny Freire (autora da resenha)

Jornalista (UFRN), mestre em Estudos da Mídia (PPgEM/UFRN) e doutoranda em Comunicação Social (PPgCOM/UERJ). Trabalha com cultura, sociedade, música, editoração e identidade. Membro do grupo de pesquisa CAC - Comunicação, arte e cidade. E-mail: libnyfreire@gmail.com 